Article

\title{
An Analysis of Stormwater Management Variants in Urban Catchments
}

\author{
Mariusz Starzec 1,*(D) Józef Dziopak and Daniel Słyś(i) \\ Department of Infrastructure and Water Management, Rzeszow University of Technology, al. Powstańców \\ Warszawy 6, 35-959 Rzeszow, Poland; jdziopak@prz.edu.pl (J.D.); daniels@prz.edu.pl (D.S.) \\ * Correspondence: mstarzec1990@prz.edu.pl
}

Received: 20 January 2020; Accepted: 18 February 2020; Published: 20 February 2020

\begin{abstract}
In order to identify the most effective variants for reducing flood risk in cities and to provide protection for water resources, an in-depth study was carried out. The research results allowed for the identification of sustainable drainage infrastructure solutions that should be used to increase the efficiency of traditional drainage systems. The most effective solution turned out to be the simultaneous use of low impact development facilities and stormwater flow control devices in drainage systems (Variant IV). Applicationof this variant (maximum discharge QOmax $=246.39$ $\mathrm{dm}^{3} / \mathrm{s}$ ) allowed for the reduction of the peak flow by as much as $86 \%$ in relation to those values that were established in the traditional drainage system (maximum discharge $Q O \max =1807.62 \mathrm{dm}^{3} / \mathrm{s}$ ). The use of Variant IV allowed for a combination of the advantages of low impact development (LID) facilities and stormwater flow control devices in drainage systems while limiting their disadvantages. In practice, the flow of rainwater from the catchment area to the drainage system was limited, the share of green areas increased, and the drainage system retention capacity grew. The proposed approach for reducing the increasing flood risk in cities and providing protection for water resources provides a structured approach to long-term urban drainage system planning and land use guidelines.
\end{abstract}

Keywords: stormwater management; retention sewage canal; sustainable drainage systems; urban floods; management of water resources; climate change

\section{Introduction}

The development of urban agglomerations has been taking place on an unprecedented scale in the last decade [1,2]. Currently, approximately 55\% of the world's population lives in urban areas. It is estimated that this ratio will increase up to $68 \%$ by 2050 [3]. An increase of social and logistical problems and the deterioration of the natural environment are negative consequences of urbanization [4-6]. In order to ensure the maintenance of the living standards that are expected by residents, who are increasing in number, it is necessary to properly maintain, operate $[7,8]$, and modernize a city's infrastructure $[9,10]$ and to implement such in accordance with the principles of sustainable development [11,12]. In many cases, urban development is constrained by the possibilities of municipal infrastructure, especially the one used to drain wastewater and stormwater $[13,14]$.

Urbanization increases the sealing of existing drainage basins, which causes, among other effects, changes in the dynamics and size of surface runoff and a decreased intensity of groundwater supply $[15,16]$. Currently, the uncontrolled and reckless replacement of biologically active areas with impervious surfaces has been observed $[17,18]$. In catchments that are characterized by a significant percentage of green areas, the transformation of rainfall into surface and underground runoff occurs much more slowly and in a sustainable way $[19,20]$. The prevailing volume of precipitation in these areas is subject to infiltration, evaporation, and surface retention [21]. Only a small part of the volume of rainfall transforms into surface runoff $[22,23]$. Unfortunately, as the degree of sealing of the drainage 
basin increases, the proportion between these processes changes. In catchments with a high degree of sealing, the infiltration of rainwater into the ground disappears in favor of a surface runoff, which in cities goes almost entirely to the drainage systems [24-26].

Local urban floods are an increasingly observed phenomena, typical in highly urbanized areas. They result from the occurrence of heavy rainfall, the intensity of which exceeds the possibilities of their hydraulic transport by municipal drainage systems $[27,28]$. Other times, dry periods occur in the same areas when water scarcity is observed $[29,30]$. The occurrence of drought within urban agglomerations has a negative impact on society, the economy, and the natural environment. The growing population of a city also necessitates a greater amount of the total water that is needed for adequate municipal supply [31]. Reducing the risk of natural disasters (e.g., floods and drought) requires the effective management of water resources [32] and advanced seasonal forecasting [33]. Proper water management in urban areas allows for the transformation of rainwater, which is treated as a problem, into an alternative source of water [17,34]. Though these types of floods usually cover a part of the drainage basin, their occurrence causes significant financial and social losses [35,36]. Outflows of stormwater from drainage systems to the surface of area usually occur in close proximity to drainage conduits, which have an insufficient hydraulic capacity. There are also cases where the flooding appears at a considerable distance from the overloaded conduit, and this is due to the specific shape of the catchment surface [14].

It is also worth emphasizing that there are often situations in which conduits are not completely used in terms of hydraulics and have significant unused capacity above the rainwater table that can be included in the retention volume of the drainage system [37]. This fact is of colossal significance in the aspect of slowing down rainwater runoff to receivers and limiting their negative impact, but it is also very important for economic reasons [38,39].

Urban floods have become a major problem for most urban agglomerations around the world. At present, it is believed that the best way to deal with excess rainwater in such areas is to use objects and devices that allow for the reconstruction of the natural water cycle that occurred in areas before their urbanization [40-42]. These facilities include rain gardens, permeable pavement, rainwater catchment, vegetated (green) roofs, and soil amendments for better absorption. Green infrastructure that mimics natural hydrological processes is able to provide economic, environmental, and social benefits [43,44]. According to research [45-50], for stormwater management practices in urban areas, the main purpose of most types of low impact development (LID) devices is a reduction of the peak discharge of stormwater. For instance, the installation of wales and rain-gardens can improve the greening of cities and increase the overall area of urban greenery. This can in turn improve the diversity of urban ecosystems by providing new habitats for a wider range of organisms (e.g., birds, amphibians, and insects) [51-55]. In addition, the use of LID facilities can improve water quality [56-59] and reduce air pollution [60-65]. The careful planning of such infrastructures can also bring many benefits to the general public as a result of creating more recreational space (e.g., urban parks) and improving the utility value of a district or urban areas $[17,66]$.

There are certain situations in which low impact development practices are not recommended or impossible to apply in practice. While the infiltration of rainwater into the ground is usually desirable, diverting water to some locations can create problems, e.g., destabilizing slopes and cliffs [67]. The use of green infrastructure facilities in the process of creating the concept of sustainable drainage systems requires a compliance with appropriate local and soil-water conditions. The use of infiltration facilities is justified only in areas with an appropriate filtration coefficient $k f$ and low groundwater levels [42]. The use of low impact development devices enables the solving of the problem of excess rainwater in the local range [68]. In order to ensure sustainable rainwater management in an urban agglomeration, these techniques should be applied throughout the whole catchment area [36]. An LID infrastructure system requires significant space to be reserved for its construction. For example, the use of bio-swales on roads should be allocated an additional space between pedestrians, cycle lanes and 
roads, and housing estates should be provided with sufficiently large areas for the construction of tanks or draining devices [67].

In urban catchments that are subject to strong expansion it is very difficult or sometimes impossible to obtain free land for building water and stormwater management facilities. In such cases, underground drainage disposal systems are used, which, when taking the solution of innovative retention canals proposed by the authors of the publication into account, are characterized by a better environmental impact and much better economic parameters that are associated with the more effective use of the retention capacity of the drainage systems.

The article analyzes various variants of drainage and management of rainwater from the city's catchment area with particular emphasis on the proprietary solution of innovative retention canals and low impact development facilities. As part of the research, four stormwater management options had their peak discharges determined and their advantages and disadvantages identified. The presented results indicate that the simultaneous use of piling partitions and LID devices allows for the achievement of the highest economic, environmental and social benefits in comparison to the currently used variants of stormwater management, i.e., the traditional drainage system, low impact development practices, and retention sewage canals.

\section{Materials and Methods}

\subsection{Case Study}

The research was carried out for a real catchment area constituting a fragment of the city of Tarnobrzeg, which is located in south-eastern Poland (Figure 1).

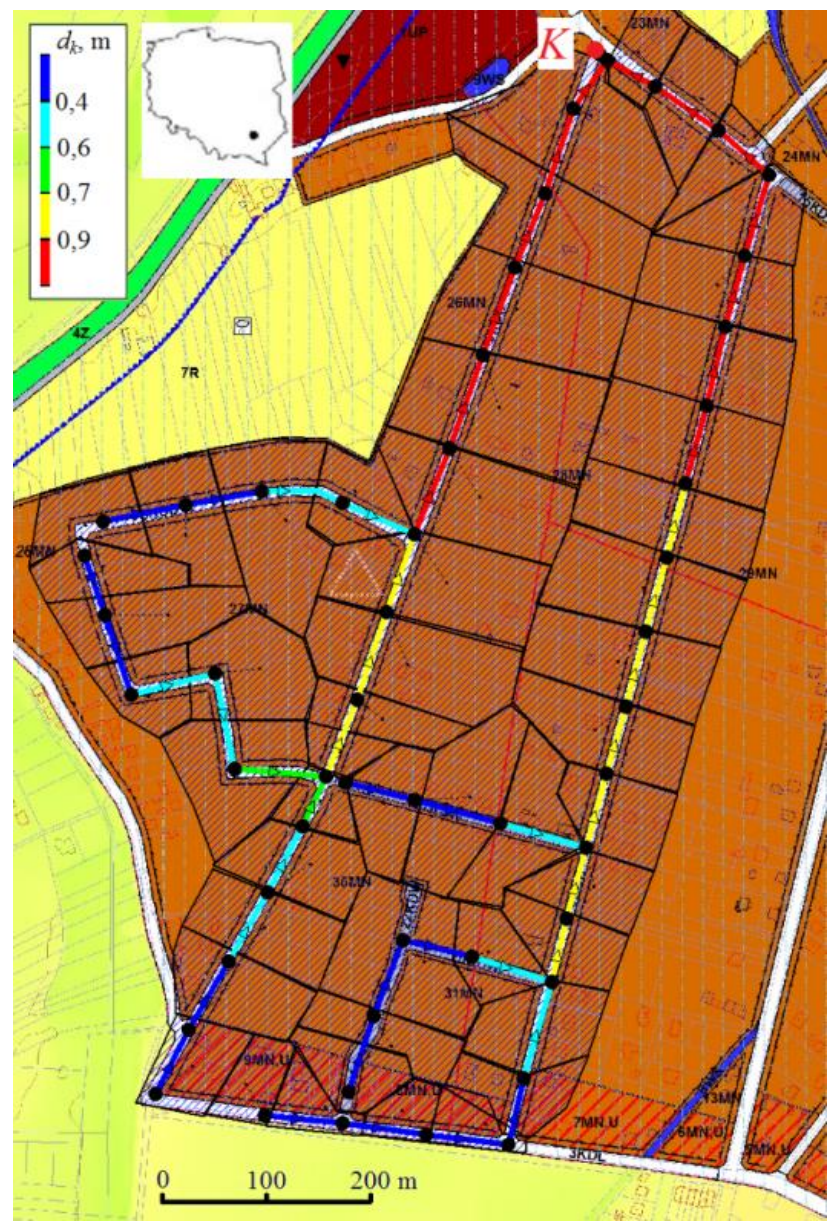

Figure 1. Scheme of the drainage basin ( $K$-drainage system outlet node; $d_{k}$-conduit diameter). 
The parameters characterizing the catchment are presented in Table 1.

Table 1. Land-use characteristics of the urban catchment.

\begin{tabular}{ccc}
\hline \multirow{2}{*}{ Land Use } & \multicolumn{2}{c}{ Area } \\
\cline { 2 - 3 } & (ha) & $\mathbf{( \% )}$ \\
\hline Rooftop & 4.78 & 10.30 \\
Road, pavement and other impervious & 9.60 & 20.70 \\
\hline Green area & 32.00 & 69.00 \\
\hline Total areas & 46.38 & 100.00 \\
\hline
\end{tabular}

The parameters characterizing the traditional drainage system are presented in Table 2.

Table 2. Hydraulic parameters of traditional drainage system.

\begin{tabular}{ccc}
\hline \multirow{2}{*}{ Parameter } & \multicolumn{2}{c}{ Value } \\
\cline { 2 - 3 } & Minimum & Maximum \\
\hline Length of links & $19.36 \mathrm{~m}$ & $97.40 \mathrm{~m}$ \\
\hline Total length of links & \multicolumn{2}{c}{$3769.70 \mathrm{~m}$} \\
Slope of links & $1.1 \%$ o & $3.1 \% \mathrm{o}$ \\
Diameter of links & $0.3 \mathrm{~m}$ & $1.0 \mathrm{~m}$ \\
\hline Drainage system capacity & \multicolumn{2}{c}{$1515.76 \mathrm{~m}^{3}$} \\
\hline
\end{tabular}

The precipitation model of Bogdanowicz and Stachy (recommended in Poland) was used to calculate the unit precipitation intensity [69]. This model determines the correlations between the intensity of precipitation and its duration, using Equation (1):

$$
h_{\max }=1.42 \cdot t_{d}^{0.33}+\alpha\left(t_{d}\right) \cdot(-\ln p)^{0.584}
$$

where $h_{\max }$ is the maximum total amount of precipitation with a duration $t_{d}$ and a probability of occurrence $p(\mathrm{~mm}), \alpha$ is a parameter (scale) that is adopted depending on the region of Poland and the duration of precipitation $t_{d}, p$ is the probability of rainfall: $p \in(0 ; 1]$, and $R$ is a region of Poland.

All simulations were carried out while assuming a probability of rainfall as $p=0.5$. Precipitation intensity was estimated according to the Bogdanowicz and Stache formula concerning block precipitation with a uniform intensity throughout their duration. Figure 2 shows the IDF (Intensity-Duration-Frequency) curve that was determined on the basis of Equation (1).

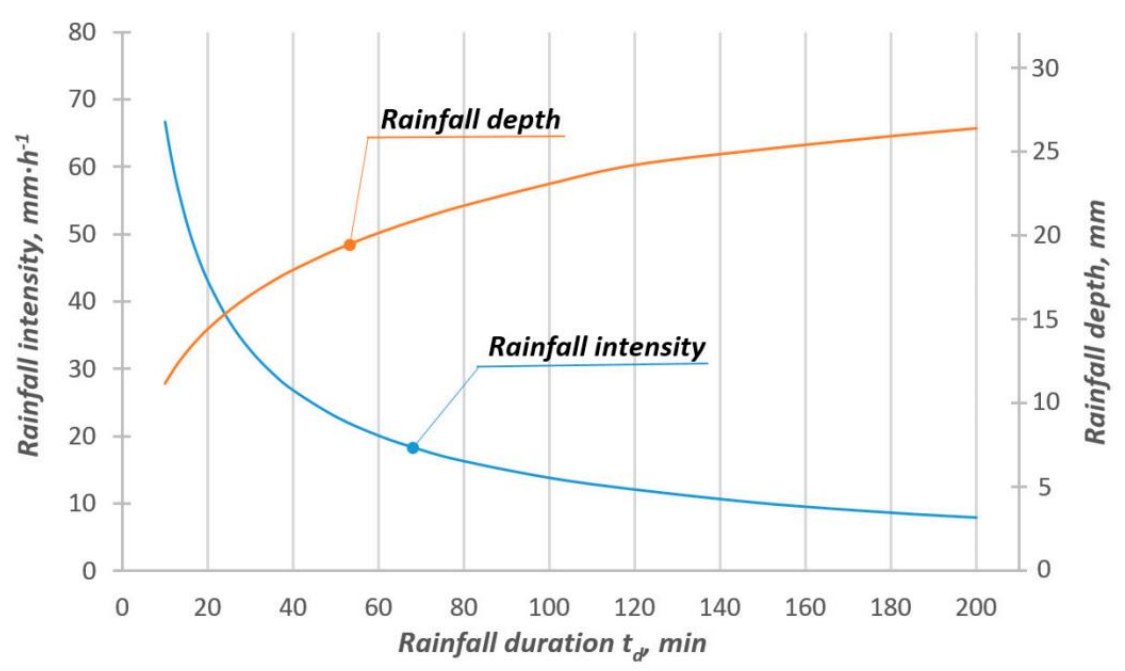

Figure 2. IDF curve determined based on the Bogdanowicz and Stache model at $p=0.5$ 


\subsection{Storm Water Management Model (SWMM)}

A simulation of hydrological and hydraulic phenomena occurring in the "precipitation-drainage and basin-drainage system-receiver" system was carried out by using the Storm Water Management Model (SWMM) version 5.1 program. Hydrodynamic models of the drainage system made in the SWMM program allowed for the determination of the values of the hydraulic parameters describing the operation of the drainage system in variable conditions of its function (static and dynamic), including flow rate and liquid stream velocity, hydrostatic pressure, and rainwater filling height in the drainage system canal. A diagram illustrating the transformation of precipitation into surface runoff in the SWMM program is presented in Figure 3.

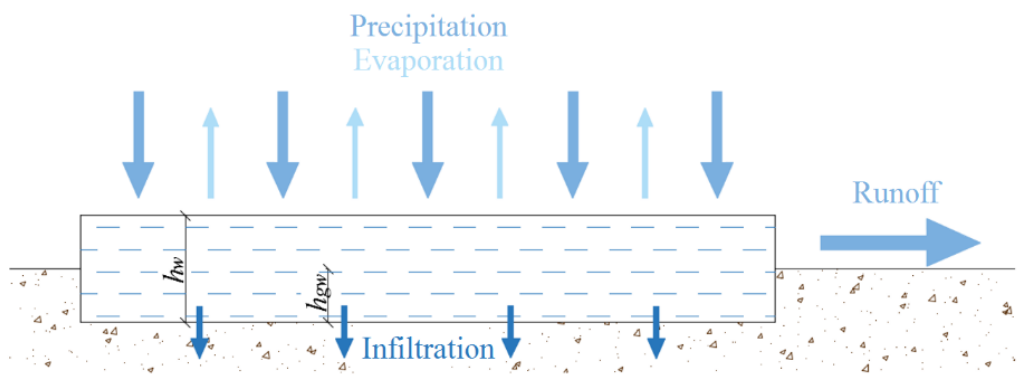

Figure 3. Conceptual view of surface runoff in the Storm Water Management Model (SWMM) 5.1 ( $h_{w}$-depth of water over the subcatchment; $h_{g w}$-depth of depression storage) [70].

Each subcatchment was treated as a non-linear reservoir. Therefore, the reliable outflow from the subcatchment was determined on the basis of the relationship presented by Equation (2) [70]:

$$
Q_{p}=p_{s} \frac{\left(h_{w}-h_{g w}\right)^{\frac{3}{5}}}{n_{z}} i_{z}^{\frac{1}{2}}
$$

where $Q_{p}$ is the surface runoff intensity of rainwater, $p_{s}$ is the runoff width of the drained drainage basin, $h_{w}$ is the depth of the water over the subcatchment, $h_{g w}$ is the depth of depression storage, $n_{z}$ is the Manning coefficient for the drainage basin, and $i_{z}$ is the slope of drainage basin.

The instantaneous intensity of rainwater outflow from the catchment corresponds to the volume of water stored on its surface, with less losses resulting from water infiltration into the ground, evaporation, and surface retention height. The value of the instantaneous rainwater flow rate in a drainage system conduits in the SWMM 5.1 program is determined based on the system of differential Equation (3), which results from the principles of mass conservation (continuity Equation (3)) and momentum (momentum Equation (4)), as developed by de Saint-Venant in Equation (3) [70]:

$$
\text { Continuity : } \frac{\partial A}{\partial t}+\frac{\partial Q}{\partial x}=0
$$

$$
\text { Momentum : } \frac{\partial Q}{\partial t}+\frac{\partial\left(Q^{2} / A\right)}{\partial x}+g A \frac{\partial H}{\partial x}+g A S_{f}+g A h_{L}=0
$$

where $x$ is the distance along the conduit, $t$ is time, $A$ is the cross-sectional area, $Q$ is the flow rate, $H$ is the hydraulic head of water in the conduit (elevation head plus any possible pressure head), $S_{f}$ is the friction slope (head loss per unit length), $h_{L}$ is the local energy loss per unit length of the conduit, and $g$ is the acceleration of gravity.

The SWMM program user has the opportunities to choose one of three derived models resulting from the adoption of certain simplifications in the de Saint-Venant equation. All simulations were performed by assuming a dynamic wave model.

The LID control module allows for the simulation of the operation of various types of low impact development infrastructure. The user can model eight different types of LID control devices, i.e., 
bio-retention cells, rain gardens, green roofs, infiltration trenches, continuous permeable pavement, rain barrels, rooftop disconnection, and vegetative swales [70].

\subsection{Sustainable Urban Drainage Systems (RETENTION SEWAGE CANAL)}

The improvement of the hydraulic efficiency of traditional drainage systems has been achieved by introducing piling partitions to manholes (Figure 4).
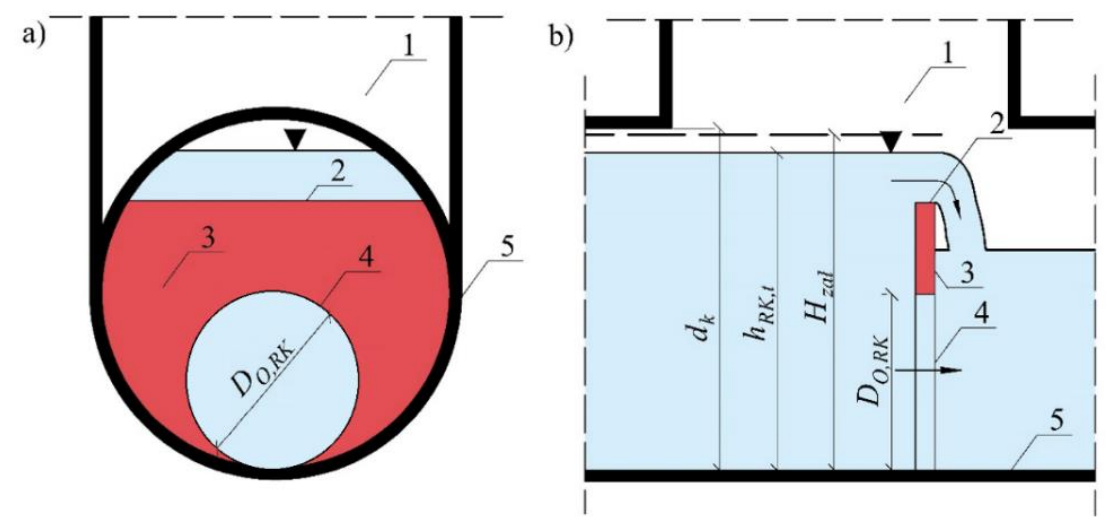

Figure 4. Diagram of the implementation and location of the piling partitions in a manhole (a) cross section and (b) longitudinal section. 1-manhole/sewer chamber; 2-emergency overflow; 3-piling partition; 4-outflow orifice; 5-conduit; $H_{z a t}$-maximum allowable stormwater fill before the piling partition; $h_{R K, t}$-instantaneous stormwater fill height in the drainage system conduit equipped with a retention system during the time $t ; d_{k}$-diameter of the conduit; and $D_{O, R K}$-diameter/height of the outflow orifice) $[14,71]$.

The piling partition had an outflow orifice (4) in the lower part, and the upper edge of the partition was a typical front overflow (2). The circular outflow orifice (4) was mapped in the SWMM program by using the Orifice Link function. The emergency overflow (2) was designed by using the Weir Link function.

The principle of operation of the retention sewage network is shown in Figure 5.

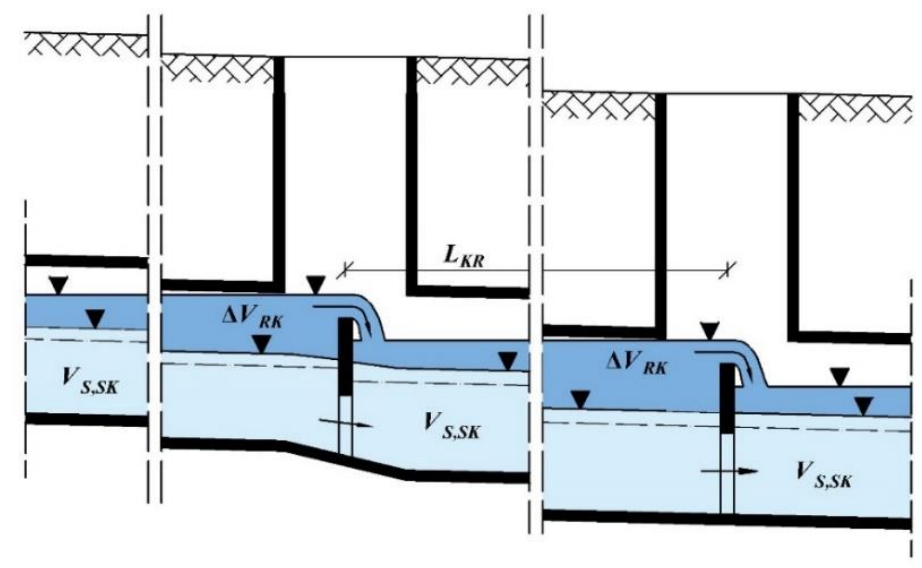

Figure 5. Scheme of the retention sewage canal with piling partitions that create stormwater canal retention spaces (blue-average distribution of the liquid stream mirror in the conduits of a traditional drainage systems and the blue-liquid stream distribution and retention capacity of the drainage system after equipping it with piling partition; $V_{S, S K}$ - the volume of stormwater retained in the drainage system; $\Delta V_{R K}$-the additional volume of stormwater retained in the conduits between the drainage system operating in a traditional way and an identical drainage system equipped with a system of retention sewage canal; and $L_{K R}$ - distance between adjacent piling partitions) [72]. 
Piling partitions form a serial hydraulic system of retention chambers on a drainage system and make it possible to effectively use the capacity of the drainage system [73]. The application of the aforementioned solution provides measurable effects and has a number of application advantages, in particular, it allows for the significant reduction of peak-flow values at subsequent stages of hydraulic transport of stormwater, which has already been confirmed many times as part of many investments in Poland [71].

\section{Results}

Four variants of drainage systems were adopted in the research.

Variant I-urban drainage with rainwater drainage by a traditional underground gravity drainage system (Figure 6).

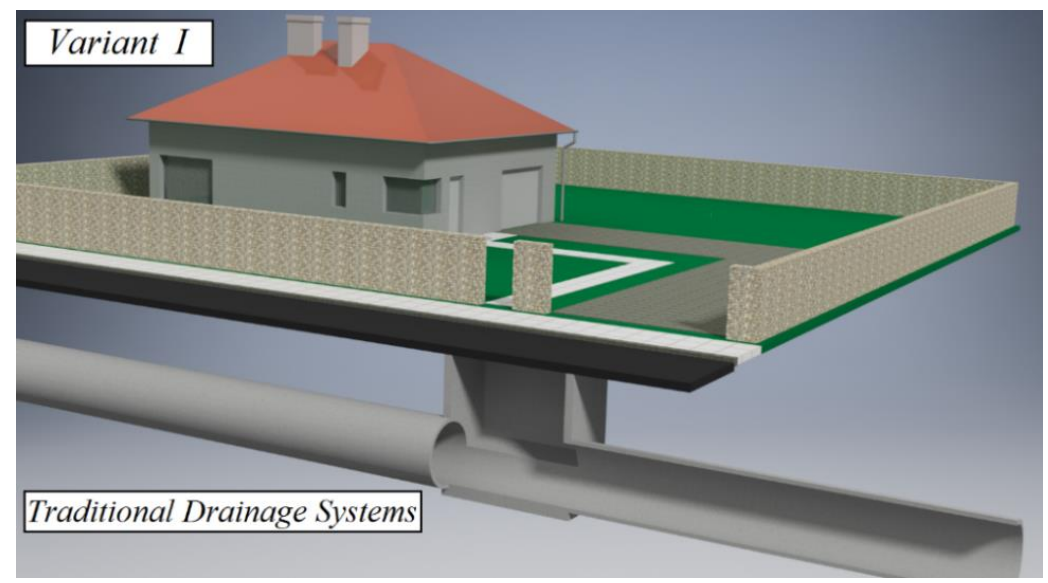

Figure 6. The principle of rainwater management in Variant I (traditional drainage systems).

Variant II-rainwater management based on the interaction of a traditional drainage system with low impact development facilities (Figure 7). It was assumed in the research that rainwater from the roofs of buildings would be drained to rain gardens, which were located on individual properties. The rain garden parameters are shown in Table 3.

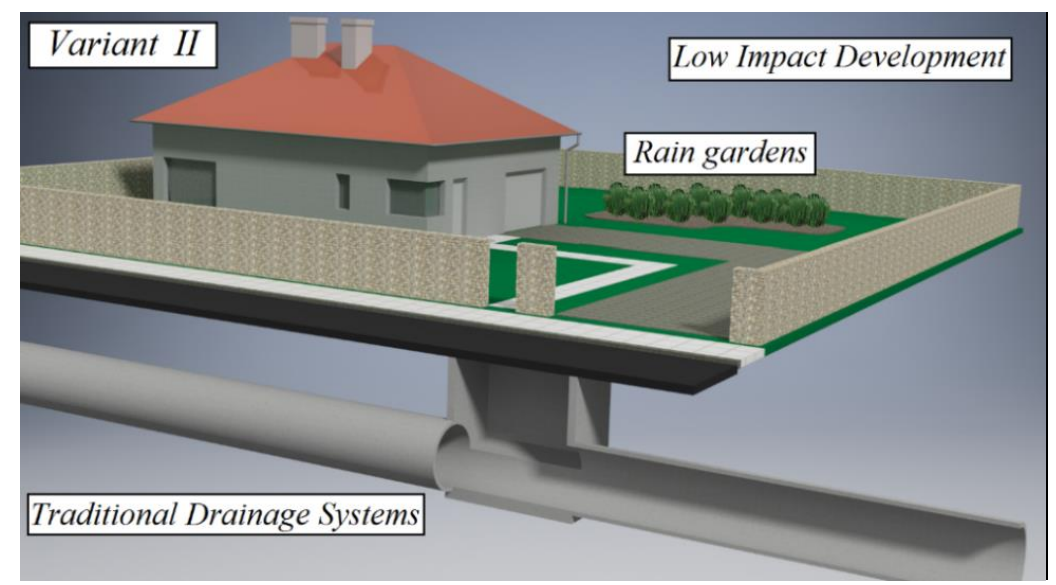

Figure 7. The principle of rainwater management in Variant II (traditional drainage systems and low impact development (LID) facilities).

Variant III—urban drainage with rainwater drainage by a sustainable drainage system (a traditional drainage system equipped with piling partitions) (Figure 8), in accordance with a patent solution [50]. The average distance between the piling partitions of the retention sewage canals was approximately equal $75 \mathrm{~m}$. The ratio parameter $H_{z a t} / d_{k}$ was equal to 0.99 . 
Variant IV-rainwater management in the catchment area based on the use of a traditional drainage system equipped with both low impact development devices and piling partitions (Figure 9).

Table 3. Properties of layers of rain gardens.

\begin{tabular}{cc}
\hline Layers & Value \\
\hline Surface layer & \\
\hline Berm height & $80 \mathrm{~mm}$ \\
Vegetation volume fraction & 0.1 (volume fraction) \\
Surface roughness (Manning $\mathrm{n})$ & $0.052 \mathrm{~m}^{-1 / 3} \mathrm{~s}$ \\
Surface slope & $1.0 \%$ \\
\hline Soil layer & \\
\hline Thickness & $900 \mathrm{~mm}$ \\
Porosity & 0.33 (volume fraction) \\
Field capacity & 0.24 (volume fraction) \\
Wilting point & 0.15 (volume fraction) \\
Conductivity & $10 \mathrm{~mm} / \mathrm{h}$ \\
Conductivity slope & 1 \\
Suction head & $5 \mathrm{~mm} / \mathrm{h}$ \\
\hline
\end{tabular}

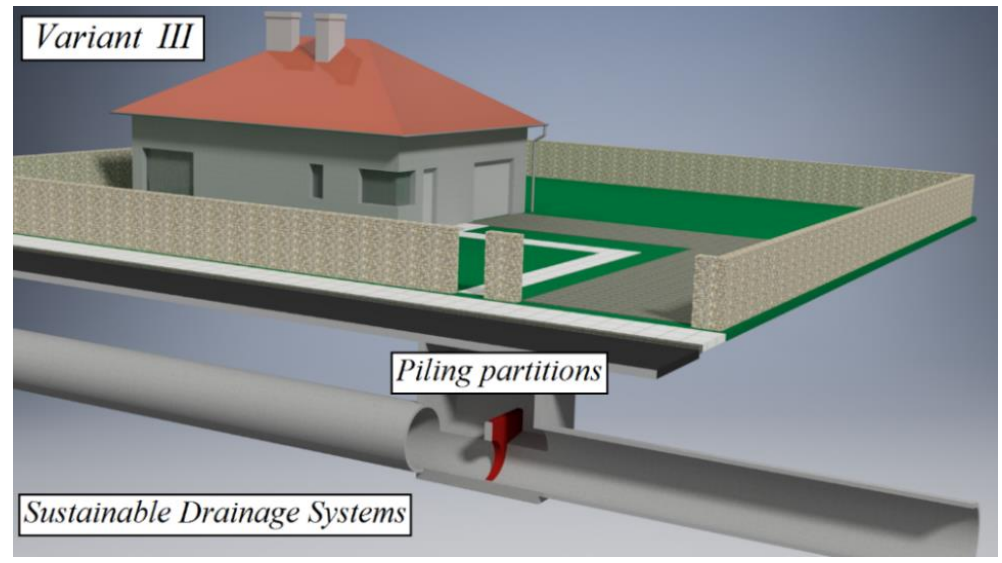

Figure 8. The principle of rainwater management in Variant III (traditional drainage systems and piling partitions).

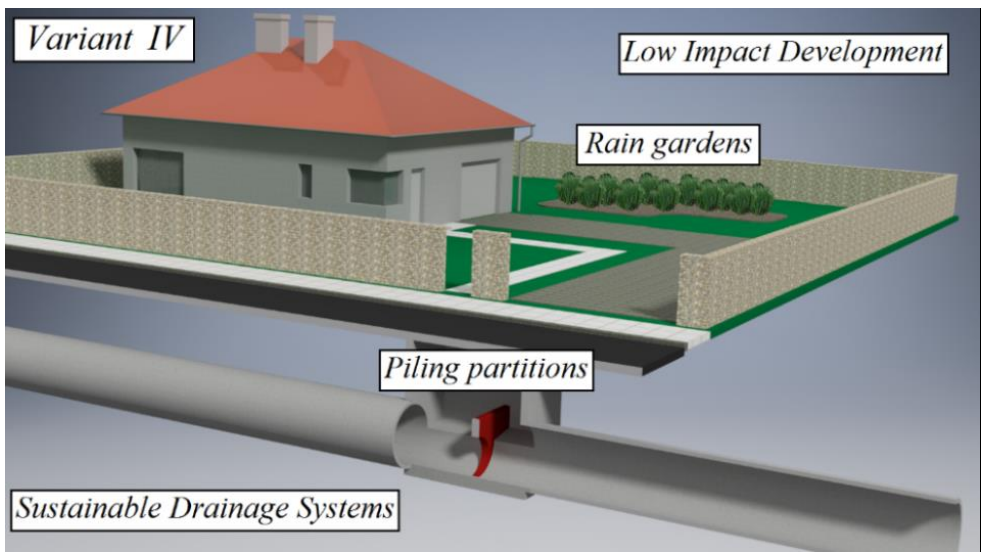

Figure 9. The principle of rainwater management in Variant IV (traditional drainage systems, piling partitions, and LID facilities). 
The simulation tests of four variants of the drainage system showed significant differences in the size and dynamics of rainwater outflows. First of all, there were significant differences in the variability of QO stormwater runoff from this system, as shown in Figure 10.
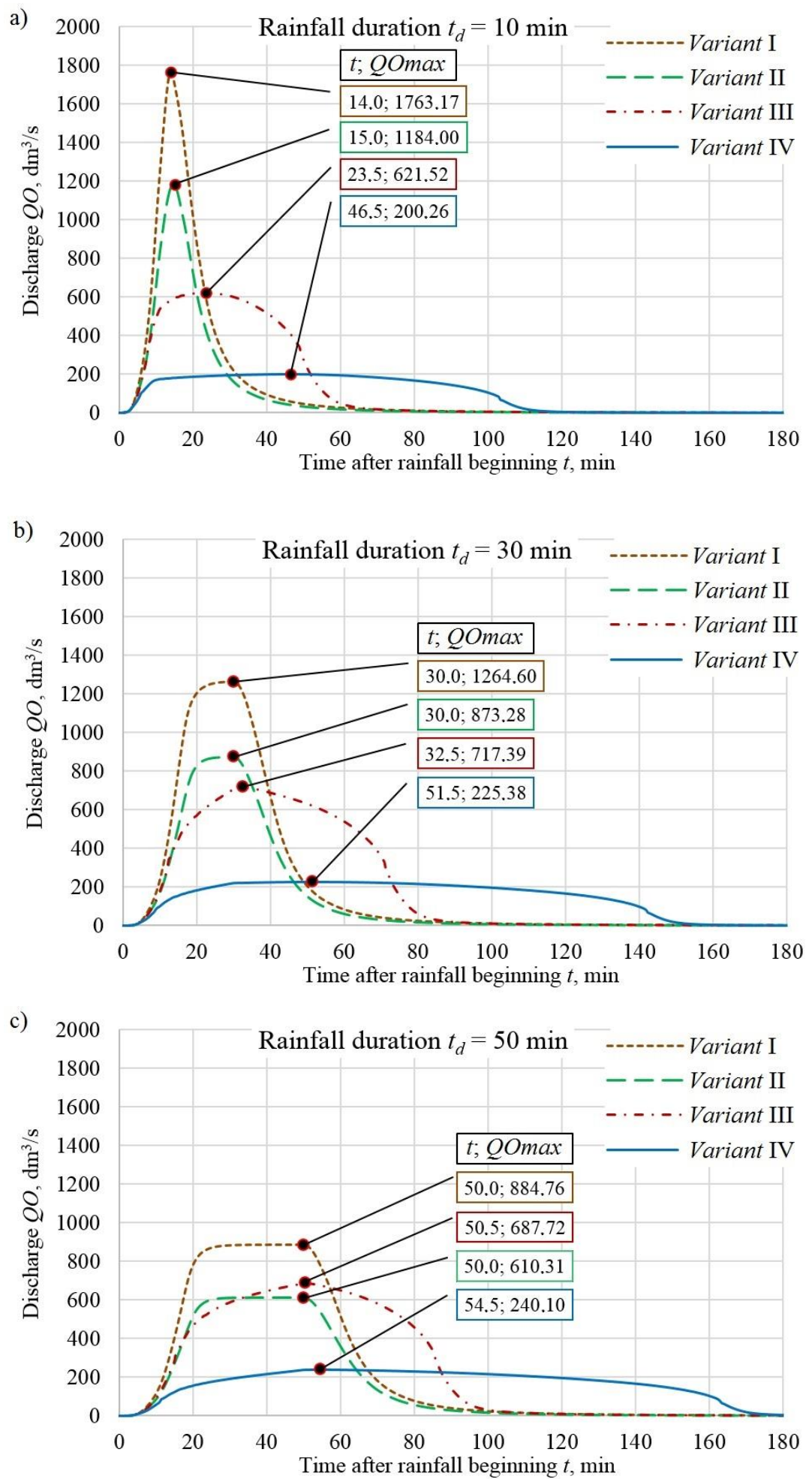

Figure 10. Hydrographs of stormwater runoff from the gravitational drainage systems at the outlet node $K$ depending on the examined variants of its function and the duration of precipitation (a) $t_{d}=$ $10 \mathrm{~min},(\mathbf{b}) t_{d}=30 \mathrm{~min}$, and (c) $t_{d}=50 \mathrm{~min}$. 
For example, by analyzing the data that were obtained during rainfall with a duration of $t_{d}=$ 10 min (Figure 10a), it could be seen that the peak flow rate QOmax decreased from the value of 1763.17 $\mathrm{dm}^{3} / \mathrm{s}$ in Variant I to just $200.26 \mathrm{dm}^{3} / \mathrm{s}$ with the system in operation Variant IV. At the same time, the stormwater retention time in the drainage system in Variant IV, about 110 minutes, was almost three times longer compared to the value of this parameter that was determined for Variant I, which had a value of almost 40 minutes.

Conducting tests in a sufficiently wide range of precipitation times $t_{d}$ (precipitation with a duration of 10 to $160 \mathrm{~min}$ ) allowed for the establishment the relationship between the peak outflow rates QOmax from the drainage system in relation to the duration of precipitation $t_{d}$. The results of the tests are presented in graphic form in Figure 11.

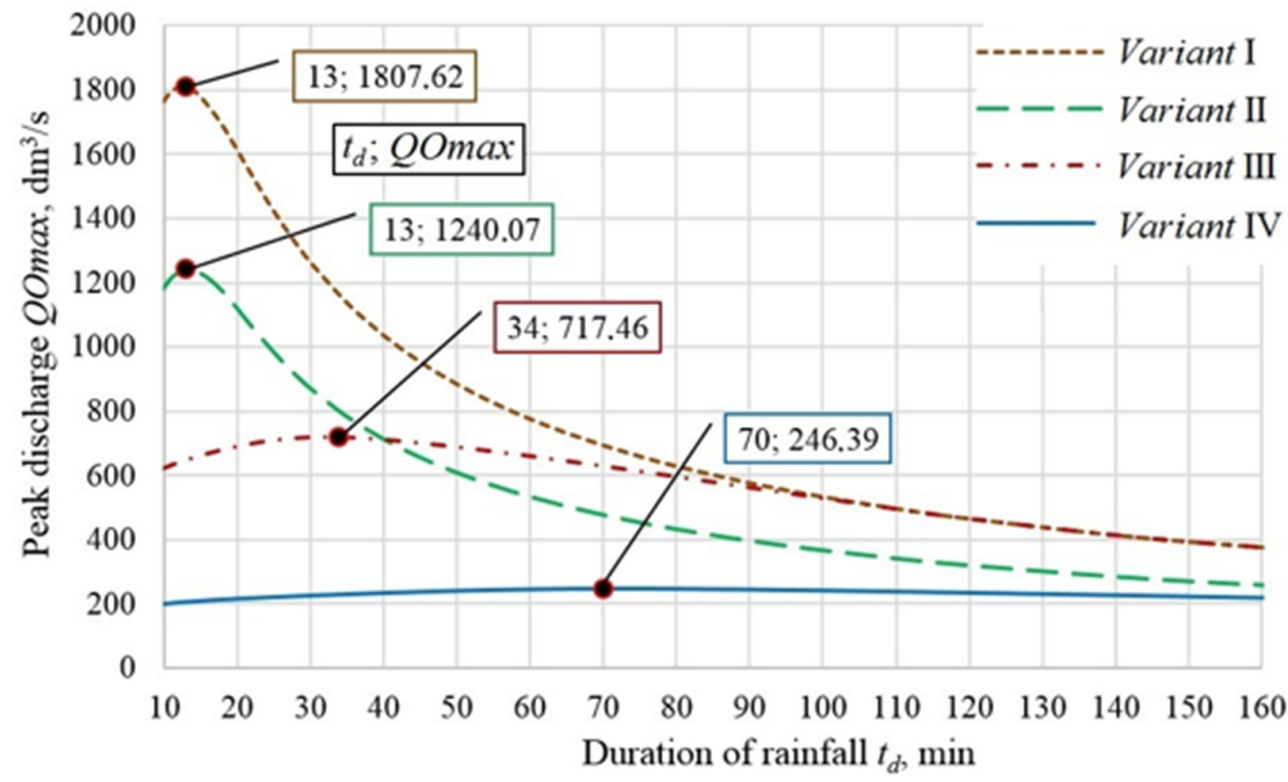

Figure 11. Hydrographs of rainwater runoff from the gravitational stormwater drainage systems at the outlet node $K$ depending on the examined variants of its function and the duration of rain (a) $t_{d}=$ $10 \mathrm{~min},(\mathbf{b}) t_{d}=30 \mathrm{~min}$, and $(\mathbf{c}) t_{d}=50 \mathrm{~min}$ ).

It turned out that the most unfavorable hydrograph of the rainwater outflow from the analyzed catchment occurred in the case of Variant I, i.e., the traditional drainage system. Regardless of the considered duration of rainfall $t_{d}$, the adoption of Variant I resulted in the highest values of peak outflow from the examined catchment. At the same time, it could be seen that the time of stormwater detention in the drainage system and the outflow to the receiver was the shortest for all rainfall times $t_{d}$.

Variant IV had the greatest ability to extend the time of outflow from the catchment area and to reduce the volume of flows, consisting of the simultaneous use of an innovative retention drainage system and low impact development devices. The best results were noted both in terms of the volume of the rainwater flowing into the drainage system from the drained drainage basin and the reduction in the size of the outflows from the drainage basin to the receiver.

A comparison of the set peak outflow rates from the tested drainage systems proved that the adopted stormwater management variant had a very significant impact on the hydraulic load of the rainwater receiver. The highest values of the peak flow rate of the stormwater QOmax were observed in Variant I, regardless of the considered duration of rainfall $t_{d}$. Intermediate test results were obtained in the case of analysis of Variants II and III. It turns out that in Variant III during short rainfall, i.e., with $t_{d}<40$ minutes, the use of piling partitions allowed for the obtainment of much more favorable hydraulic conditions at the outflow from the drainage basin under test conditions compared to the use of low impact development facilities (Variant II). In the event of rainfall with a duration of $t_{d}>$ 40 minutes, the use of LID objects was found to be more preferable. 
The research showed that Variant IV guaranteed the highest safety of the hydraulic function of the drainage system under test conditions. By analyzing the results of simulation tests on a real urban catchment, it was found that the use of Variant IV reduced the peak rainfall outflow intensity from 1807.62 to just $246.39 \mathrm{dm}^{3} / \mathrm{s}$. Importantly, the use of Variant IV in practice, based on sustainable drainage system supported by LID devices, allowed for the obtainment of a practically constant value of the peak outflow from the drained drainage basin, regardless of the duration of precipitation $t_{d}$ (Figure 11). At the same time, the $Q O$ stormwater outflow rates (Figure 10) maintained values that were close to the peak value, practically throughout the entire period of the hydraulic function of the drainage system. This is an important observation, primarily for practical reasons, because it allows for a significant reduction in investment and operating costs of existing drainage facilities and their equipment that are located downstream drainage systems, i.e., after the outlet node $K$.

The confirmed relationship is particularly important in the case of the temporary storage of stormwater runoff in underground vaults, pounds, or depressed area to allow for metered discharges that reduce peak flow rates, as well as the storage of stormwater runoff in site. Obtaining a favorable hydrograph of inflow to these objects (smaller and stable value of the inflow intensity) makes it possible to reduce their required volume.

The use of the retention capacity of the drainage system (retention sewage canal) and limiting the inflow of rainwater (low impact development) to this system has allowed for the reduction of the peak outflow from this system. It turns out that the largest reduction in the peak flow of stormwater, by as much as $86 \%$ compared to Variant I, was ensured by the use of Variant IV. An indirect reduction of the peak flow of $60 \%$ was found when Variant II taking into account. On the other hand, the use of LID devices in Variant III reduced the peak flow by $31 \%$.

\section{Discussion}

Xia et al. [74] described the concept of using green infrastructure as a breakthrough in the planning of urban areas. This approach to flood risk management in cities is desirable because it provides recreational space, habitats for various organisms, and mitigates other adverse urbanization effects such as the heat island effect. The results of the tests confirmed the correctness of this thesis. However, in order to increase the effectiveness of practices to reduce the risk of urban floods, it is necessary to take into account the interaction of the green LID infrastructure with facilities to increase the retention efficiency of drainage systems (retention sewage canal).

A review of the literature in the discussed topic and analyses of the results of the simulation tests allowed for the determination of the basic advantages and disadvantages of the four flood risk management options in urban areas and indicated the fields of their practical application; these are listed in Table 4.

The conducted research confirmed that the use of traditional sewage systems (Variant I) is an inefficient way of dealing with excess rainwater in urban areas. The acceptance of this outdated approach leads to the frequent occurrence of urban floods, causing significant social and financial losses. In the case of a concept based on green infrastructure (Variant II), the correctness of its application in urban agglomeration was confirmed. It should be noted, however, that, in addition to the indisputable advantages, the system based on LID devices also has disadvantages that sometimes limit the area of their practical applications. In turn, the use of the concept based on the use of only the retention capabilities of drainage systems gives very good results in terms of its hydraulic efficiency. It is highly purposeful to include such a solution in design concepts. It allows one to simultaneously control and reduce the peak values of stormwater flows. Unfortunately, in Variant III, the entire volume of rainwater that drains from the drained drainage basin to the rainwater drainage system is discharged to the receiver, which is a significant drawback. 
Table 4. Advantages and disadvantages of analyzed variants of rainwater management in urban areas.

\begin{tabular}{|c|c|c|}
\hline Variant & Advantages & Disadvantages \\
\hline I & $\begin{array}{l}\text {-Minimal demand for built-up space, especially on the land surface. } \\
\text {-High resistance to adverse soil and water conditions. } \\
\text {-No requirements regarding the quality of transported stormwater. } \\
\text {-Can be used in areas with different buildings } \\
\text {-Possibility of using trenchless methods during the investment. }\end{array}$ & $\begin{array}{l}\text {-Lack of utilization of retention capabilities of active channels in these systems. } \\
\text {-Adverse hydrograph of rainwater runoff from the system (cumulative peak rainfall } \\
\text { discharges to the receiver). } \\
\text {-The entire volume of rainwater transported by the system is discharged outside the } \\
\text { drainage basin. } \\
\text {-Deterioration of the receiver's water quality by introducing impurities contained } \\
\text { in rainwater. }\end{array}$ \\
\hline II & $\begin{array}{c}\text {-Ability to temporarily rainwater retention. } \\
\text { Possibility of interoperability of LID devices with other drainage infrastructure. } \\
\text {-Limiting the volume of stormwater discharged outside the drainage basin. } \\
\text {-Improvement of soil and water conditions in the catchment area. } \\
\text {-Imitation of natural hydrological processes before urbanization. } \\
\text {-Rainwater pretreatment. } \\
\text {-Possibility of rainwater supply by existing traditional sewage systems. } \\
\text {-Possibility of cooperation of various LID objects within the drained drainage basin. } \\
\text {-Improving the diversity of urban ecosystems, including providing new habitats for a } \\
\text { wider range of organisms. } \\
\text {-Recreation space and improvement of the utility value of a district or urban areas. }\end{array}$ & $\begin{array}{c}\text {-Frequent necessity of pre-treatment of rainwater before it is fed to soil infiltration } \\
\text { devices. } \\
\text {-The need for periodic maintenance of LID devices. } \\
\text {-Dependence on soil and water conditions } \\
\text {-Dependence on area availability. } \\
\text {-A significant share of the required area of LID facilities in relation to the drained } \\
\text { drainage basin. } \\
\text {-Often possible high investments. }\end{array}$ \\
\hline III & $\begin{array}{c}\text {-All benefits of Variant I. } \\
\text {-Using the retention possibilities of existing drainage systems. } \\
\text {-A favorable hydrograph of rainwater outflow from the system (low and constant } \\
\text { rainfall outflow intensity). } \\
\text { - The possibility of applying various LID objects to the drainage system. }\end{array}$ & $\begin{array}{c}\text {-The entire volume of rainwater transported by the system is discharged outside the } \\
\text { drainage basin. } \\
\text {-Reduction of the load per unit load of the receiver's water pollution. } \\
\text {-Deterioration of the receiver's water quality by introducing impurities contained } \\
\text { in rainwater. } \\
\text {-Dependence of the retention capacity of the drainage system on the average bottom } \\
\text { of its ducts, equipped with retention canals. }\end{array}$ \\
\hline IV & $\begin{array}{l}\text { - Benefits of Variants II and III. } \\
\text { - The maximum possible reduction of the peak outflow from the drained } \\
\text { drainage basin. } \\
\text { - The possibility of limiting the use of LID facilities in places where their operation is } \\
\text { expensive and/or difficult to implement. } \\
\text { - Limitation of the required geometry of drainage system, especially in areas with } \\
\text { permeable soils. }\end{array}$ & $\begin{array}{l}\text {-Frequent necessity of pre-treatment of rainwater supplied to devices before } \\
\text { infiltration into the ground. } \\
\text {-Periodic maintenance of LID devices is required. } \\
\text {-Dependence on soil and water conditions for LID facilities. } \\
\text {-Dependence on the availability of land for the construction of LID facilities. }\end{array}$ \\
\hline
\end{tabular}


Thus, the most desirable approach to the problem of excess rainwater is the implementation of Variant IV. It combines the advantages of Variant II and Variant III while limiting their disadvantages. In addition, the special advantage of the presented Variant IV is the easy transition from Variant II or III to Variant IV.

Municipal authorities have sometimes expressed the view that the main reason for frequent urban floods and drought is climate change, not the lack of a consistent balanced approach to storm water management. For instance, in more than $90 \%$ of Chinese cities, flood risk management is based on the use of traditional engineering infrastructure [17] in the form of a traditional covered storm water drainage systems, which are designed to discharge urban discharges to the receiver as soon as possible. Additionally in Poland, as in many other European Union countries, traditional drainage systems that operate in a gravitational way are still the leading way of transporting rainwater [14] when draining urbanized areas. This approach results rainwater discharge that is characterized by a high peak flow value and a rapid rise of water in the receivers.

Widely exploited traditional drainage systems, which have great retention capacity, have created a wide field of application for the design variant presented in Variant III. Of course, if local conditions allow it, it is optimal to adopt Variant IV, based on the use of modernized sustainable drainage systems that are supported by LID devices. Variant IV allows for the use of existing engineering infrastructure to control urban outflows and the storage of rainwater during extreme rainfall. This practice will provide opportunities to solve a number of problems related to rainwater and the urban environment that are currently being solved by traditional drainage systems. It can be safely stated that the implementation of the concept of using sustainable drainage systems that are supported by low impact development devices is a revolutionary approach in creating a spatial plan for urban development and storm water management in cities, along with a rational desire to reduce the risk of urban floods. The validity of this concept is confirmed by the fact that there is an increasing involvement in many countries in introducing low impact development facilities to projects globally.

To sum up, commonly used traditional drainage systems with significant retention possibilities have created a wide field for an application of solutions presented in Variant IV, which consist of the simultaneous application of modernized sustainable drainage systems that are supported by LID devices.

\section{Conclusions}

This article analyzes various variants of dealing with rainwater on the example of a housing estate that is located in Poland. Rainwater management that is based on the simultaneous use of sustainable drainage systems with specific water storage capacities and low impact development facilities should be considered the most advantageous. The obtained set of hydraulic simulation results made it possible to determine and then compare the effectiveness of all four adopted variants in terms of their impact on the drainage system and rainwater receiver.

The analyses showed that the implementation of Variant IV, which uses system retention in the drainage system and LID facilities, allowed for a reduction the peak flow and the volume of rainwater that is discharged from the drained drainage basin. The results of the research revealed that in the studied catchment area, the use of Variant IV reduced the peak discharge of rainwater by $86 \%$ compared to Variant I. Variant IV had the highest hydraulic efficiency among the tested variants, regardless of the duration of the storm $t_{d}$. In addition, the advantage of the drainage system with piling partitions (Variant III) over the drainage system with LID facilities (Variant II) was demonstrated during a short rainfall. Thus, the use of retention capacity of drainage systems through the implementation of, e.g., a retention sewage canal, can be an effective alternative to LID objects.

To sum up, Variant IV allows for the combination of the advantages of rainwater storage and LID facilities while limiting their disadvantages. The application of the proposed Variant IV will undoubtedly allow for the achievement of a high level of flood safety and the strengthening of the 
ecological and recreational values of cities while reducing the costs that are associated with the investment and operation of the engineering facilities used.

The research results presented in this paper have practical applications and may be used as guidelines for potential investors early as in the investment planning stage and, furthermore, as a tool for promoting the application of the simultaneous use of retention sewage canal and low impact development facilities. The study outlined above indicates the need to continue the research work concerning the reliability of stormwater management practice. This work will be oriented at the assessment of operating qualities of the proposed stormwater management practice in real-life conditions.

Author Contributions: Conceptualization, M.S., J.D. and D.S.; methodology, M.S., J.D. and D.S.; investigation, M.S.; writing—original draft preparation, M.S.; writing—review and editing, M.S.; supervision, J.D. and D.S. All authors have read and agreed to the published version of the manuscript.

Funding: This research received no external funding.

Acknowledgments: The author would like to thank the reviewers for their feedback, which has helped improve the quality of the manuscript. We would also like to thank the Resources' staff and Editors for handling the paper.

Conflicts of Interest: The authors declare no conflict of interest.

\section{References}

1. Słyś, D.; Stec, A. Centralized or Decentralized Rainwater Harvesting Systems: A Case Study. Resources 2020, 9, 5. [CrossRef]

2. Hu, S.; Fan, Y.; Zhang, T. Assessing the Effect of Land Use Change on Surface Runoff in a Rapidly Urbanized City: A Case Study of the Central Area of Beijing. Land 2020, 9, 17. [CrossRef]

3. Nations United. The World Population. Available online: https:/www.un.org/development/desa/en/news/ population/2018-revision-of-world-urbanization-prospects.html (accessed on 13 January 2020).

4. Kordana, S. SWOT analysis of wastewater heat recovery systems application. E3S Web Conf. 2017, 17, 00042. [CrossRef]

5. Sarabi, S.E.; Han, Q.; Romme, A.G.L.; de Vries, B.; Wendling, L. Key Enablers of and Barriers to the Uptake and Implementation of Nature-Based Solutions in Urban Settings: A Review. Resources 2019, 8, 121. [CrossRef]

6. Guneralp, B.; Lwasa, S.; Masundire, H.; Parnell, S.; Seto, K.C. Urbanization in Africa: Challenges and opportunities for conservation. Environ. Res. Lett. 2018, 13, 015002. [CrossRef]

7. Papciak, D.; Tchórzewska-Cieślak, B.; Domoń, A.; Wojtuś, A.; Żywiec, J.; Konkol, J. The Impact of the quality of tap water and the properties of installation materials on the formation of biofilms. Water 2019, 11, 1903. [CrossRef]

8. Tchórzewska-Cieślak, B.; Pietrucha-Urbanik, K.; Papciak, D. An Approach to Estimating Water Quality Changes in Water Distribution Systems Using Fault Tree Analysis. Resources 2019, 8, 162. [CrossRef]

9. Kaykhosravi, A.; Abogadil, K.; Khan, U.; Jadidi, M. The Low-Impact Development demand index: A new approach to identifying locations for LID. Water 2019, 11, 2341. [CrossRef]

10. Hornbuckle, J.W.; Christen, E.W.; Faulkner, R.D. Evaluating a multi-level subsurface drainage system for improved drainage water quality. Agric. Water Manag. 2017, 89, 208-216. [CrossRef]

11. Abbas, O.; Abou Rjeily, Y.; Sadek, M.; Shahrour, I. A large-scale experimentation of the smart sewage system. Water Environ. J. 2017, 31, 515-521. [CrossRef]

12. Pochwat, K.; Kida, M.; Ziembowicz, S.; Koszelnik, P. Odours in Sewerage-A Description of Emissions and of Technical Abatement Measures. Environments 2019, 6, 89. [CrossRef]

13. Rodriguez-Sinobas, L.; Zubelzu, S.; Perales-Momparler, S.; Canogar, S. Techniques and criteria for sustainable urban stormwater management. The case study of Valdebebas (Madrid, Spain). J. Cleaner Prod. 2018, 172, 402-416. [CrossRef]

14. Dziopak, J. A wastewater retention canal as a sewage network and accumulation reservoir. E3S Web Conf. 2018, 45, 00016. [CrossRef]

15. Bruni, G.; Reinoso, R.; van de Giesen, N.C.; Clemens, F.H.L.R.; ten Veldhuis, J.A.E. On the sensitivity of urban hydrodynamic modelling to rainfall spatial and temporal resolution. Hydrol. Earth Syst. Sci. 2015, 19, 691-709. [CrossRef] 
16. da Silva, C.V.F.; Schardong, A.; Garcia, J.I.B.; Oliveira, C.D.M. Climate change impacts and flood control measures for highly developed urban watersheds. Water 2018, 10, 829. [CrossRef]

17. Chan, F.K.S.; Griffiths, J.A.; Higgitt, D.; Xu, S.Y.; Zhu, F.F.; Tang, Y.T.; Xu, Y.Y.; Thorne, C.R. "Sponge City" in China-A breakthrough of planning and flood risk management in the urban context. Land Use Policy 2018, 76, 772-778. [CrossRef]

18. Yue, H.; Li, L.; Yu, Y. Does urban cluster promote the increase of urban eco-efficiency? Evidence from Chinese cities. J. Cleaner Prod. 2018, 197, 957-971. [CrossRef]

19. Zdeb, M.; Zamorska, J.; Papciak, D.; Styś, D. The quality of rainwater collected from roofs and the possibility of its economic use. Resources 2020, 9, 12. [CrossRef]

20. Talib, A.; Randhir, T.O. Climate change and land use impacts on hydrologic processes of watershed systems. J. Water Clim. Change 2017, 8, 363-374. [CrossRef]

21. Zeleňáková, M.; Hluštík, P.; Abd-Elhamid, H.F.; Vranayová, Z.; Markovič, G.; Hudáková, G.; Tometz, L. Comprehensive study of the percolation of water from surface runoff with an emphasis on the retention capacity and intensity of precipitation. Water Sci. Technol. 2019, 79, 2407-2416. [CrossRef]

22. Pochwat, K. Hydraulic analysis of functioning of the drainage channel with increased retention capacity. E3S Web Conf. 2017, 17, 00075. [CrossRef]

23. Todeschini, S.; Papiri, S.; Ciaponi, C. Placement Strategies and Cumulative Effects of Wet-weather Control Practices for Intermunicipal Sewerage Systems. Water Resour. Manag. 2018, 32, 2885-2900. [CrossRef]

24. Sadeghi, K.M.; Loaiciga, H.A.; Kharaghani, S. Stormwater control measures for runoff and water quality management in urban landscapes. J. Am. Water Resour. Assoc. 2018, 54, 124-133. [CrossRef]

25. Dietz, M.E.; Clausen, J.C. Stormwater runoff and export changes with development in a traditional and low impact subdivision. J. Environ. Manag. 2008, 87, 560-566. [CrossRef] [PubMed]

26. Yang, X.H.; Ye, N.; Li, M.S. Comprehensive assessment of low impact development for urban stormwater control measure - a case study of bioretention. Basic Clin. Physiol. Pharmacol. 2016, 119, 30-33.

27. Buurman, J.; Babovic, V. Adaptation Pathways and Real Options Analysis: An approach to deep uncertainty in climate change adaptation policies. Policy Soc. 2016, 35, 137-150. [CrossRef]

28. Wang, M.; Zhang, D.Q.; Adhityan, A.; Ng, W.J.; Dong, J.W.; Tan, S.K. Assessing cost-effectiveness of bioretention on stormwater in respons to climate change and urbanization for future scenarios. J. Hydrol. 2016, 543, 423-432. [CrossRef]

29. Morehouse, B.J.; Carter, R.H.; Tschakert, P. Sensitivity of urban water resources in Phoenix, Tucson, and Sierra Vista, Arizona, to severe drought. Clim. Res. 2002, 21, 283-297. [CrossRef]

30. March, H.; Domenech, L.; Sauri, D. Water conservation campaigns and citizen perceptions: The drought of 2007-2008 in the Metropolitan Area of Barcelona. Nat. Hazards 2013, 65, 1951-1966. [CrossRef]

31. Seckler, D.; Barker, R.; Amarasinghe, U. Water scarcity in the twenty-first century. Int. J. Water Resour. Dev. 1999, 15, 29-42. [CrossRef]

32. Bokal, S.; Grobicki, A.; Kindler, J.; Thalmeinerova, D. From national to regional plans-The Integrated Drought Management Programme of the Global Water Partnership for Central and Eastern Europe. Weather Clim. Extremes 2014, 3, 37-46. [CrossRef]

33. Grillakis, M.G.; Koutroulis, A.G.; Tsanis, I.K. Improving Seasonal Forecasts for Basin Scale Hydrological Applications. Water 2018, 10, 1593. [CrossRef]

34. Ghosh, R.; Kansal, A.; Venkatesh, G. Urban Water Security Assessment Using an Integrated Metabolism Approach—Case Study of the National Capital Territory of Delhi in India. Resources 2019, 8, 62. [CrossRef]

35. Wartalska, K.; Kaźmierczak, B.; Nowakowska, M.; Kotowski, A. Analysis of hyetographs for sewer systems modeling. Water 2020, 12, 149. [CrossRef]

36. Noblega, A.; Sauri, D.; March, H. Community Involvement in the Implementation of Sustainable Urban Drainage Systems (SUDSs): The Case of Bon Pastor, Barcelona. Sustainability 2020, 12, 510. [CrossRef]

37. Starzec, M.; Dziopak, J.; Słyś, D. Designing a retention sewage canal with consideration of the dynamic movement of precipitation over the selected urban catchment. In Underground Infrastructure of Urban Areas 4, 4th ed.; Madryas, C., Kolonko, A., Nienartowicz, B., Szot, A., Eds.; CRC Press: London, UK, 2017; Volume 1, pp. 193-200. ISBN 9781138559530.

38. Stec, A.; Słyś, D. Effect of development of the town of Przemyśl on operation of its sewerage system. Ecol. Chem. Eng. S 2013, 20, 381-396. [CrossRef] 
39. Ngamalieu-Nengoue, U.A.; Martínez-Solano, F.J.; Iglesias-Rey, P.L.; Mora-Meliá, D. Multi-objective optimization for urban drainage or sewer networks rehabilitation through pipes substitution and storage tanks installation. Water 2019, 11, 935. [CrossRef]

40. Mazzotta, M.J.; Besedin, E.; Speers, A.E. A Meta-Analysis of hedonic studies to assess the property value effects of low impact development. Resources 2014, 3, 31-61. [CrossRef]

41. Mahmoodzadeh, M.; Mukhopadhyaya, P.; Valeo, C. Effects of extensive green roofs on energy performance of school buildings in four north american climates. Water 2020, 12, 6. [CrossRef]

42. Kordana, S. The identification of key factors determining the sustainability of stormwater systems. E3S Web Conf. 2018, 45, 00033. [CrossRef]

43. Cui, T.; Long, Y.; Wang, Y. Choosing the LID for urban storm management in the south of Taiyuan basin by comparing the storm water reduction efficiency. Water 2019, 11, 2583. [CrossRef]

44. Dong, R.; Zhang, X.; Li, H. Constructing the ecological security pattern for Sponge City: A sase study in Zhengzhou, China. Water 2019, 11, 284. [CrossRef]

45. Fletcher, T.D.; Shuster, W.; Hunt, W.F.; Ashley, R.; Butler, D.; Arthur, S.; Trowsdale, S.; Barraud, S.; Semadeni-Davies, A.; Bertrand-Krajewski, J.L.; et al. SUDS, LID, BMPs, WSUD and more-The evolution and application of terminology surrounding urban drainage. Urban Water J. 2015, 12, 525-542. [CrossRef]

46. Ishaq, S.; Hewage, K.; Farooq, S.; Sadiq, R. State of provincial regulations and guidelines to promote low impact development (LID) alternatives across Canada: Content analysis and comparative assessment. J. Environ. Manag. 2019, 235, 389-402. [CrossRef]

47. Elliott, A.H.; Trowsdale, S.A. A Review of Models for Low Impact Urban Stormwater Drainage. Environ. Model. Softw. 2007, 22, 394-405. [CrossRef]

48. Coffman, L.S.; Goo, R.; Frederick, R. Low-Impact Development An Innovative Alternative Approach to Stormwater Management. In Proceedings of the 29th Annual Water Resources Planning and Management Conference, Tempe, AZ, USA, 6-9 June 1999; pp. 1-10.

49. Vogel, J.R.; Moore, T.L.; Coffman, R.R.; Rodie, S.N.; Hutchinson, S.L.; McDonough, K.R.; McLemore, A.J.; McMaine, J.T. Critical Review of Technical Questions Facing Low Impact Development and Green Infrastructure: A Perspective from the Great Plains. Water Environ. Res. 2015, 87, 849-862. [CrossRef]

50. Johns, C.; Shaheen, F.; Woodhouse, M. Green Infrastructure and Stormwater Management in Toronto: Policy Context and Instruments, Centre for Urban Research and Land Development; Centre for Urban Research and Land Development: Toronto, ON, Canada, 2018.

51. Moore, T.L.C.; Hunt, W.F. Ecosystem service provision by stormwater wetlands and ponds-A means for evaluation? Water Res. 2012, 46, 6811-6823. [CrossRef]

52. Hassall, C.; Anderson, S. Stormwater ponds can contain comparable biodiversity to unmanaged wetlands in urban areas. Hydrobiologia 2015, 745, 137-149. [CrossRef]

53. Taylor, J.R.; Lovell, S.T. Urban home food gardens in the Global North: Research traditions and future directions. Agric. Hum. Values 2014, 31, 285-305. [CrossRef]

54. Hostetler, M.; Allen, W.; Meurk, C. Landscape and Urban Planning Conserving urban biodiversity? Creating green infrastructure is only the first step. Landsc. Urban Plan. 2011, 100, 369-371. [CrossRef]

55. Pinho, P.; Correia, O.; Lecoq, M.; Munzi, S.; Vasconcelos, S.; Gonçalves, P.; Rebelo, R.; Antunes, C.; Silva, P.; Freitas, C.; et al. Evaluating green infrastructure in urban environments using a multi-taxa and functional diversity approach. Environ. Res. 2016, 147, 601-610. [CrossRef] [PubMed]

56. Mao, X.; Jia, H.; Yu, S.L. Assessing the ecological benefits of aggregate LID-BMPs through modelling. Ecol. Model. 2017, 353, 139-149. [CrossRef]

57. Schifman, L.A.; Prues, A.; Gilkey, K.; Shuster, W.D. Realizing the opportunities of black carbon in urban soils: Implications for water quality management with green infrastructure. Sci. Total Environ. 2018, 644, 1027-1035. [CrossRef] [PubMed]

58. Xie, N.; Akin, M.; Shi, X. Permeable concrete pavements: A review of environmental benefits and durability. J. Clean. Prod. 2019, 210, 1605-1621. [CrossRef]

59. Seo, M.; Jaber, F.; Srinivasan, R.; Jeong, J. Evaluating the Impact of Low Impact Development (LID) Practices on Water Quantity and Quality under Different Development Designs Using SWAT. Water 2017, 9, 193. [CrossRef] 
60. Capotorti, G.; Alós Ortí, M.M.; Copiz, R.; Fusaro, L.; Mollo, B.; Salvatori, E.; Zavattero, L. Biodiversity and ecosystem services in urban green infrastructure planning: A case study from the metropolitan area of Rome (Italy). Urban For. Urban Green. 2019, 37, 87-96. [CrossRef]

61. Morakinyo, T.E.; Lam, Y.F.; Hao, S. Evaluating the role of green infrastructures on near-road pollutant dispersion and removal: Modelling and measurement. J. Environ. Manag. 2016, 182, 595-605. [CrossRef]

62. Nordbo, A.; Järvi, L.; Haapanala, S.; Wood, C.R.; Vesala, T. Fraction of natural area as main predictor of net CO2 emissions from cities. Geophys. Res. Lett. 2012, 39. [CrossRef]

63. Chenoweth, J.; Anderson, A.R.; Kumar, P.; Hunt, W.F.; Chimbwandira, S.J.; Moore, T.L.C. The interrelationship of green infrastructure and natural capital. Land Use Policy 2018, 75, 137-144. [CrossRef]

64. Rafael, S.; Vicente, B.; Rodrigues, V.; Miranda, A.I.; Borrego, C.; Lopes, M. Impacts of green infrastructures on aerodynamic flow and air quality in Porto's urban area. Atmos. Environ. 2018, 190, 317-330. [CrossRef]

65. Jayasooriya, V.M.; Ng, A.W.M.; Muthukumaran, S.; Perera, B.J.C. Green infrastructure practices for improvement of urban air quality. Urban For. Urban Green. 2017, 21, 34-47. [CrossRef]

66. Wang, Y.; Sun, M.; Song, B. Public perceptions of and willingness to pay for sponge city initiatives in China. Resour. Conserv. Recycl. 2017, 122, 11-20. [CrossRef]

67. Ministry of Housing and Urban-Rural Development. The Constructionguideline of Sponge City in China-Low Impact Development of Stormwater System(trail); Ministry of Housing and Urban-Rural Development: Beijing, China, 2014.

68. Benzerra, A.; Cherrared, M.; Chocat, B.; Cherqui, F.; Zekiouk, T. Decision support for sustainable urban drainage system management: A case study of Jijel, Algieria. J. Environ. Manag. 2012, 101, 46-53. [CrossRef] [PubMed]

69. Bogdanowicz, E.; Stachy, J. Maximum Rainfall in Poland. Design Characteristics, 1st ed.; The Publishing House of the Institute of Meteorology and Water Management: Warsaw, Poland, 1998; p. 83.

70. Rossman, L.A. Storm Water Management Model User's Manual Version 5.1. United States Environmental Protection Agency. Available online: https://www.epa.gov/water-research/storm-water-management-modelswmm (accessed on 13 January 2020).

71. Słyś, D. An innovative retention canal-A case study. E3S Web Conf. 2018, 45, 00084. [CrossRef]

72. Słyś, D.; Dziopak, J. Retention Sewage Canal; Patent Office of the Republic of Poland: Warsaw, Poland, 2014; p. 217405.

73. Starzec, M. The impact of construction of piling partitions on the retention efficiency of a sewerage network. E3S Web Conf. 2018, 45, 00087. [CrossRef]

74. Xia, J.; Zhang, Y.; Xiong, L.; He, S.; Wang, L.; Yu, Z. Opportunities and challenges of the Sponge City construction related to urban water issues in China. Sci. China Earth Sci. 2017, 60, 652-658. [CrossRef]

(C) 2020 by the authors. Licensee MDPI, Basel, Switzerland. This article is an open access article distributed under the terms and conditions of the Creative Commons Attribution (CC BY) license (http://creativecommons.org/licenses/by/4.0/). 